logicznych (brak „finezji i lekkości”), trudno nie docenić wysiłku tłumacza i redaktora tego tomu, który sam przyznał, iż tłumaczenie tych tekstów stanowiło dlań ,wyzwanie" translatorskie.

$\mathrm{W}$ ten sposób powstała antologia ma za cel „zaznajomienie czytelnika polskiego z nieznana mu dotąd szerzej przeszła i teraźniejszą niemiecką refleksja teoretyczno-historyczną i (...) literaturoznawcza nad pisarstwem historycznym" 2 . Motywem przewodnim prezentowanych tekstów jest problem stosunku narracji historycznej do narracji literackiej oraz zależności między narracja historyczną a rzeczywistością pozatekstowa. I chociaż, jak zaznaczyl J. Kałażny, wybór tekstów był z konieczności bardzo ograniczony (aczkolwiek obją on materiały „kanoniczne": J. Ch. Gatterera, W. von Humboldta, L. von Rankego, J. G. Droysena [teksty te niejako stanowia podstawe wykształcenia historycznego], a także te, które do tej pory nie były przełożone na język polski), problem owych stosunków został wyraźnie zarysowany.

Praca podzielona została na dwie części. Pierwsza $\mathrm{z}$ nich została zatytułowana: „W stronę autonomizacji, unaukowienia i profesjonalizacji: nauka historii od oświecenia do historyzmu", druga natomiast, „Przezwyciężenie historii strukturalnej: (Zachodnio)niemiecka nauka historii w ostatnim trzydziestoleciu XX wieku". Ów podział został podyktowany niejako względami historiograficznymi; twórca antologii wziął bowiem pod uwage proces odkrywania przez historię swojej tożsamości jako nauki autonomicznej, niezależnej już od filozofii i innych dyscyplin. Prezentowana antologia ma ukazać jak na przestrzeni dziejów „zwykłe” opowiadanie historii, charakterystyczne dla późnego oświecenia i początków XIX wieku, powoli przeistoczyło się w jej analizę, czyli autonomiczna dyscyplinę. A wszystko to zostało ukazane przy uwzględnieniu „rozterki historyka, który opisując przeszłość, musi, w swoim mniemaniu, balansować miedzy estetycznym pięknem przekazu i jego merytoryczną rzetelnościa" ${ }^{3}$. Stąd w drugicj części pracy znalazły się teksty badaczy niemieckich podejmujacych problemy opowiadania historii na tle szerszej refleksji nad miejscem nauki historii pośród innych nauk $\mathrm{i}$ jej metodologicznych implikacji $w$ estetyce i poetyce ${ }^{4}$. To dlatego obok tekstów historyków i historiografów znalazły się także wykłady literaturoznawców (np. D. Harth, K. Stierle) czy filozofów (np. H. R. Jauss, H. Lubbe), a nawet psychologa (J. Straub) ${ }^{5}$. W refleksji badaczy niemieckich znalazły sıę także pytania, jak i na ile można wykorzystać opowiadanie historii w praktyce szkolnej, po co i dlaczego należy pielęgnować i opowiadać i opisywać przeszłość.

Omawiana praca poza oczywistym wypelnieniem luki wydawniczej, co już jest wartościa sama w sobie, wypehnia jeszcze inną misję: tę mianowicie aby „praktykujacy” i piszacy badacze dziejów, czytając kolejna pozycję Wydawnictwa Poznańskiego, wzięli sobie postulaty niemieckich historyków do serca i zaczęli pisać swoje książki tak, aby znalazły one swoich czytelników, których zachwyci nie tylko wiedza autorów i ich dociekliwość, ale także erudycja, piękno, finezja i lekkość języka, których często brakuje. Na szczęście nie tylko w naukach historycznych.

Edyta Glowacka-Sobiech
I s. 1 .
2 s. 7.
3 s. 43
4 s. 44 .
5 Dokładne notki o wszystkich autorach antologii znajduja się na końcu pracy.

\title{
Ewa Wiśniewska, Zakłady kształcenia nauczycieli w Płocku, Wydawnictwo Państwowej Wyższej Szkoły Zawodowej w Płocku, Płock 2004, ss. 401
}

Praca Ewy Wiśniewskiej, „Zakłady kształ. cenia nauczycieli w Płocku" jest przykładem monografii regionalnej. Monografii spełniającej wszystkie wymogi, stawiane tego typu pracom, jest przede wszystkim analityczna, wyczerpujaco daje opis wybranego zagadnienia, jest przykładem rzetelnej krytyki literatury i źródeł archiwalnych, a także przemyślanej ich interpretacji. Ponadto 
wypełnia lukę w polskiej literaturze przedmiotu, w której kwestia kształcenia nauczycieli, tak elementarna, nie jest w pełni opracowana.

Prezentowana praca dotyczy okresów 1918-1939 i 1945-1999, i jak sama autorka sugeruje we wstępie, ambicja jej było ukazać pełnię bogatych tradycji kształcenia nauczycieli w Plocku. W kręgu zainteresowań Ewy Wiśniewskiej znalazły się takie problemy, jak: zmieniające się formy instytucjonalnego kształcenia nauczycieli, plany i programy nauczania w poszczególnych zakładach kształcenia, sprawność kształcenia $w$ tych zakładach, zasady naboru uczniów i słuchaczy, modele absolwentów, kadra pedagogiczna, cele i zalożenia praktyk pedagogicznych, plany i przebieg pracy ideowo wychowawczej, rola szkół pedagogicznych w życiu i rozwoju miasta, a także naukowo-badawczy dorobek zakładów kształcenia. Autorka także jasno sprecyzowała cele badawcze: odtworzenie historii zakładów kształcenia nauczycieli w Płocku, dokonanie analizy i oceny pracy dydaktyczno-wychowawczej w prezentowanych szkołach pedagogicznych i w płockich zakladach kształcenia nauczycieli i ukazanie miejsca i roli szkół pedagogicznych w życiu i rozwoju miasta.

Praca składa się z dwóch części i podział ów jest uwarunkowany chronologia: okres międzywojenny („Ksztalcenie nauczycieli w Płocku w okresie międzywojennym") i po 1945 roku (,Kształcenie nauczycieli w Płocku w latach 1945 - 1999"). Każda z części dzjeli się na rozdziały i tutaj z kolei konstrukcja ma charakter problemowy. Autorka posłużyła się w badaniach metodologia historyczna i pedagogiczna, ze szczególnym uwzględnieniem metody porównawczej, która pozwoliła na pewne uogólnienia we wnioskach (częste braki w materialach źródłowych). Zastosowała także metody jakościowe i jakościowe, przydatne przy badaniu dokumentów i w badaniach ankietowych. Podstawą wiado- mości jednak pozostały źródła archiwalne. Autorka przeprowadziła kwerendę w Archiwum Państwowym w Plocku, Archiwum Szkolnym przy Zespole Szkół i Zakładów Kształcenia i Doskonalenia Nauczycieli w Płocku i w Archiwum Związku Nauczycielstwa Polskiego w Płocku. Ilość zgromadzonych i wykazanych akt pozwalaja sadzić, iż badania archiwalne zostały przeprowadzone rzetelnie. Uzupełnieniem źródel archiwalnych są źródła drukowane, prasa (przedstawiona, niestety, zbyt ogólnikowo), a także opracowania, artykuły (wyodrębnione niepotrzebnie, mogly bowiem być częścią składowa opracowań) oraz źródła wywołane, bardzo przydatne przy tego typu tematyce $\mathrm{i}$ jedna praca nie opublikowana.

Wynikiem analizy przeprowadzonej przez autorkę nad tak bogatym materiałem jest kilka konkluzji: po pierwsze to, iż założenia przedwojennego systemu kształcenia nauczycieli znacznie odbiegały od systemu powojennego, co podyktowane bylo odmiennymi realiami społeczno-politycznymi, a także, często sprzeczna, polityka oświatową, realizowana przez władze przed i po wojnie; po drugie autorka wykazała, iż Płock posiada bogate tradycje w zakresie szkolnictwa pedagogicznego.

Urozmaiceniem, wielce pożądanym $w$ tego typu pracach, są liczne aneksy (zestawienia, ankiety, wzory kwestionariuszy, spisy nauczycieli i uczniów, plany godzin szkolnych) i fotografie (niestety nie najlepszej jakości). Autorka umieściła także streszczenie $w$ języku angielskim i niemieckim, podała wykaz najważniejszych skrótów, wykorzystywanych w pracy, a także zestawila indeks nazwisk. Niewątpliwym walorem pracy jest także widoczna fascynacja autorki zawodem nauczyciela, co dzis, w dobie zaniku autorytetów i wszechobecnej relatywności, jest wyjatkowo cenne.

Edyta Glowacka-Sobiech 